\title{
IbM KELOMPOK MASYARAKAT MAJELIS TA'LIM (PEMBERDAYAAN MAJELIS TA'LIM MELALUI PENGEMBANGAN AGROINDUSTRI BAWANG MERAH)
}

\author{
Sri Hindarti ${ }^{1}$, Mohammad Nurhadi Sudjoni ${ }^{2}$, Nikmatul Khoiriyah ${ }^{3}$ \\ Fakultas Pertanian Universitas Islam \\ Email : hindartirudy@gmail.com \\ Fakultas Pertanian Universitas Islam Malang \\ Email :nurhadisudjoni@yahoo.com \\ Fakultas Pertanian Universitas Islam \\ Email : amway.2764770@gmail.com
}

\begin{abstract}
ABSTRAK
Kegiatan Ibm ini bertujuan melakukan pemberdayaan masyarakat melalui pengembangan agroindustri bawang merah goreng. Metode yang digunakan adalah melakukan pendidikan, pelatihan dan pendampingan pengolahan bawang merah segar menjadi bawang merah goreng. Hasil pelaksanaan Ibm dapat disimpulkan bahwa kegiatan diikuti sebanyak 21 orang peserta dengan respon sangat mendukung. Sebagian peserta berumur usia 31-40 tahun (38,09\%), pekerjaan ibu rumah tangga ((52,384\%), rata-rata pendapatan $R p$ 300.000,-Perbedaan latar belakang peserta Ibm, menyebabkan perkembangan kemandirian peserta dalam keikutsertaan dalam program Ibm tidak seragam. Dari kegiatan telah terbentuk kelompok pengolah bawang merah goreng dengan nama UD. Khairul Ummah, nama produk bawang merah goreng merk "BagorKu" dan ijin Depkes no P-IRT : P-IRT : 211351801012019. Dari aspek pasar telah terbentuk jaringan pasar baik secara langsung maupun model konsinyasi dengan beberapa Koperasil Toko di beberapa kota. Dampak kegiatan adalah kenaikan pendapatan peserta Ibm rata-rata 88,2\%. Usaha pengolahan bawang merah goreng layak dikembangkan ditunjukkan nilai $R / C$ ratio sebesar 1,4, BEP tercapai saat harga sebesar $\mathrm{Rp}$ 134.403,-/ $\mathrm{kg}$ atau 15,18 kilogram. Harga pokok penjualan sebesar Rp.22.500,-/botol @100 gram, nilai tambah sebesar 26,6\% dan imbalan kepada tenaga kerja sebesar 40,4\%, sehingga dapat membantu membuka lapangan kerja bagi masyarakat sekitarnya.
\end{abstract}

Kata Kunci: pemberdayaan, majelis ta'lim, agroindustri, bawang merah goring

\section{PENDAHULUAN}

Sebagaimana produk pertanian pada umumnya, bawang merah memiliki karakteritik yang spesifik yaitu: (1) Seasonibel, yaitu diproduksi musiman; (2) Perishabel, yaitu mudah busuk dan rusak; (3) Bulky, menyita ruang; (4) Voluminous, yaitu membutuhkan ruang atau tempat yang cukup besar; (5) diperoduksi di daerah sentra produksi yang memiliki kesesuaian agroklimat. Dari sisi permintaan, kebutuhan akan 
bawang merah oleh masyarakat berlangsung sepanjang tahun dan permintaan tersebar merata di seluruh wilayah di Indonesia. Menurut Sekretaris Direktorat Jendral Pengolahan dan Pemasaran Departemen Pertanian, Taufik Yasis saat ini konsumsi bawang merah sebesar 2,5 kg/kapita/tahun. Dengan jumlah penduduk 250 juta maka dibutuhkan bawang merah sebesar 650.000 ton, sementara persediaan bawang merah saat ini sekitar 1 juta ton. Jumlah tersebut dipenuhi dari $90 \%$ produksi dalam negeri dan $10 \%$ merupakan impor. Dengan jumlah persedian tersebut seharusnya masih surplus 350.000 ton. Namun fakta di lapangan berbeda dimana pada awal tahun 2013 masyarakat Indonesia dikejutkan oleh melonjaknya harga bawang merah yang mencapai Rp 60.000- Rp 80.000 per kilogram dari yang sebelumnya hanya berkisar Rp 12.000- Rp 20.000 per kilogram. Berbagai penyebab yang diduga menyebabkan lonjakan harga bawang merah adalah sistem perdagangan kartel yang mempermainkan komoditi tersebut, tersendatnya distribusi dan masalah-masalah yang terkait dengan produksi (kondisi iklim yang tidak menentu sampai gagal panen) (http://agritusi.com/archives/458 diakses 20 Maret 2013). Fluktuasi harga dan laju pertumbuhan penduduk Indonesia yang terus meningkat diikuti perubahan selera konsumen dimana masyarakat cenderung lebih menyukai bahan makanan siap saji. Fenomena ini menuntut untuk segera merubah orientasi petani dalam melakukan budidaya bawang merah, dari berorientasi pada produksi menjadi orientasi pasar. Direktoat Jenderal Pengolahan Dan Pemasaran Hasil Pertanian (2006) menetapkan cara yang paling tepat untuk mengangkat produksi sekaligus sebagai arah pengembangan komoditi bawang merah yaitu dengan memperbanyak home industry pengolahan bawang merah goreng di daerah sentra produksi. Melalui pengolahan bawang merah ini selain akan membantu pemasaran petani bawang merah, juga daapt mengurangi angka pengangguran di daerah sekitar industri tersebut. Sasarannya adalah terwujudnya system pengolahan dan pemasaran yang mampu menjamin stabilitas harga dan ketersediaan bawang merah yang bermutu secara mandiri.

Dalam pohon industri bawang merah memberikan gambaran bahwa produk olahan yang dapat dihasil dari bawang merah cukup bervariasi, seperti bawang merah dalam bentuk kupasan utuh dan irisan bawang merah segar mampu menaikkan nilai tambah sekitar 15- 25\%. Produk olahan bawang merah irisan kering, bawang goreng, pickles, bubuk bawang dan tepung memiliki rendeman bervariasi antara $10-80 \%$, dengan nilai tambah berkisar antara 25-30\% (Kementan, 2012). Penjelasan di atas menunjukkan bahwa prospek pengembangan produk olahan bawang merah masih sangat terbuka. Pengolahan tersebut bertujuan untuk mengawetkan dan mempertahankan mutu bawang. Selama ini bawang merah di Kab. Nganjuk hanya dijual dalam bentuk segar sehingga tidak bertahan lama untuk disimpan. Usaha pengolahan bawang merah menjadi berbagai olahan masih relatif kurang disebabkan minimnya pengetahuan masyarakat tentang tehnik-tehnik pengolahan bawang merah. Oleh karena itu pengembangan agroinndustri bawang merah merupakan suatu hal mendesak untuk dilakukan agar keragaan agribisnis bawang merah meningkat.

Kecamatan Patihanrowo merupakan salah satu diantara 20 Kecamatan yangi terdapat di Kabupaten Nganjuk, yang secara geografis merupakan kawasan dataran rendah dengan kondisi tanah alluvial hydromorf yang kurang baik untuk pertanian karena sulit menyerap air (BPS Kab. Nganjuk, 2010). Dengan kondisi lahan demikian 
kegiatan pertanian yang berkembang di daerah ini adalah tanaman tebu, sehingga di Patihanrowo didirikan pabrik Gula "Lestari" yang menjadi tumpuan hidup sebagian besar masyarakatnya dengan bekerja sebagai karyawan pada pabrik gula ini. selebihnya masyarakat bekerja sebagai PNS, pedagang. Sebagaimana diketahui bahwa pabrik gula hanya melakukan kegiatan produksi selama 6-7 bulan dalam setiap tahunnya dan setelah waktu tersebut karena tidak tersedia bahan baku tebu yang bisa diolah maka pabrik tidak melakukan kegiatan produksi. Pada saat tersebut masyarakat menganggur sehingga banyak yang melakukan urbanisasi ke kota diantaranya Surabaya, Jakarta dan kota besar lain. Sedangkan masyarakat yang tidak memiliki ketrampilan lain dan keberanian melakukan urbanisasi, biasanya akan menganggur dan bersifat pasif menunggu musim giling tebu yang akan datang. Untuk mengisi waktu luang, masyarakat khususnya para ibu aktif dalam kegiatan Masjelis Ta" lim hanya sekedar bersantai. Selama ini kegiatan yang dilakukan hanya bersifat sosial, religi dan tidak produktif.

Berdasarkan penjabaran tersebut, maka dapat disimpulkan bahwa pemberdayaan kelompok masyarakat yakni ibu-ibu Majelis Ta" lim merupakan salah satu alternatif untuk meningkatkan pendapatan masyarakat di Kec. Patihanrowo dengan memanfaatkan produk unggulan wilayah sekitarnya yakni bawang merah yang dapat ditemukan dengan mudah di pasar terdekat. Upaya ini dipandang dapat memberikan berbagai dampak positif bagi masyarakat, yakni pendapatan keluarga meningkat sehingga mampu mandiri secara ekonomi. Dampak lain adalah miningkatkan nilai tambah dan daya saing bawang merah, meningkatkan citra Kab. Nganjuk sebagai sentra produksi bawang merah di Jawa Timur khususnya dan di Indoensia, menjamin pemenuhan kebutuhan pangan dan keamanan pangan, dan dapat menggerakkan perekonomian daerah dengan munculnya usaha-usaha pendukung lainnya serta mengurangi arus urbanisasi. Oleh karena itu, perlu dilakukan upaya pemberdayaan ini melalui pendekatan pendidikan dan pelatihan serta pendampingan masyarakat desa.

\section{METODE KEGIATAN}

Untuk mengatasi persoalan pada kelompok masyarakat belum mandiri ekonomi, pengusul menawarkan solusi pemberdayaan masyarakat berbasis produk unggulan daerah yakni bawang merah. Pelaksanaan kegiatan pemberdayaan dilakukan melalui langkah-langkah sebagai berikut:

1) Analisis situasi lokasi untuk mengetahui potensi dan kebutuhan masyarakat sasaran dan ketersediaan bawang merah (bahan baku) dan bahan penunjang.

2) Sosilaisasi program dengan melakukan sarasehan dengan kelompok masyarakat sasaran mengenai program pemberdayaan melalui pengembangan agroindustri pengolahan bawang merah.

3) Pendidikan dan pelatihan pengolahan bawang merah menjadi bawang merah goreng.

4) Pembentukan kelompok pengolah yang bawang merah goreng,.

5) Praktek pengolahan bawang merah menjadi bawang merah goreng. 
6) Pengujian hasil praktek pengolahan bawang merah secara indrawi meliputi rasa, penampilan, daya tahan dan pasar (melakukan uji tingkat kesukaan konsumen terhadap produk bawang merah olahan).

7) Evaluasi hasil pengujian dan penentuan prioritas pengembangan hasil olahan bawang merah yang paling menguntungkan dan

diminati oleh konsumen. Hasil pelaksanaan program dievaluasi melalui pengamatan secara langsung, penyebaran kuisioner tentang manfaat program kepada mitra peserta program pengabdian mansyarakat, serta

kemungkinan pengembangannya secara komersial untuk meningkatkan pendapatan pemasyarakat.

8) Pengembangan home industry dengan mendampingi kelompok masyarakat sasaran

a. Praktek pengolahan bawang merah goreng.

b. Praktek pengemasan, pelabelan.

c. Perhitungan Harga Pokok Penjualan, Laba/Rugi dan BEP.

d. Praktek penetrasi pasar.

Dalam program ini partisipasi mitra adalah sebagai pelaku (subyek) kegiatan yakni sebagai pelaku utama yang merancang kegiatan pemberdayaan melalui pengembangan agroindustri pengolahan bawang merah. Sedangkan pengusul (Perguruan Tinggi) bertindak sebagai fasilitator kegiatan.

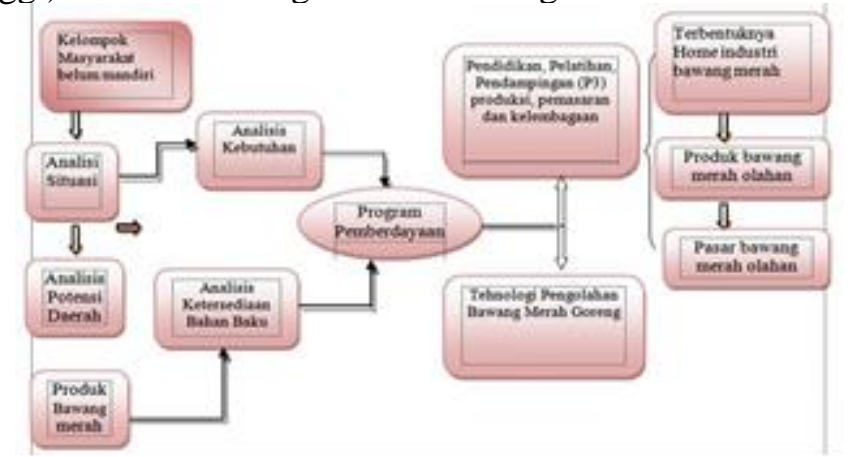

Gambar 1. Bagan Alir Pelaksanaan Kegiatan Pemberdayaan Masyarakat Melalui Pengembangan Agroindustri Bawang Merah Goreng

\section{HASIL DAN PEMBAHASAN}

\section{a. Sosialisasi Kegiatan}

Mengawali pelaksanaan kegiatan Iptek bagi Masyarakat "Pemberdayaan Majelis Ta'lim Melalui Pengembangan Agroindustri Bawang Merah" maka pada tanggal 26 April 2014 telah dilakukan kegiatan perkenalan dengan kelompok masyarakat sasaran yakni ibu-ibu yang tergabung dalam Majelis Ta'lim Khairul Ummah yang dipimpin oleh ibu Aniek Hernawati dari Rukun Warga 4 dan ibu-ibu dari Majelis Ta'lim Baitul Rahmah yang dipimpin oleh Ibu Yuyun. ibu-ibu terhadap program yang telah dirancang, melalui wawancara dengan anggota majelis. Pada kegiatan ini dihadiri 21 orang ibu-ibu. 


\section{b. Mempersiapkan Alat dan Bahan}

Sebagai persiapan awal melaksanakan kegiatan maka dilakukan kegiatan penyedian alat dan bahan yang diperlukan dalam kegiatan tersebut. Peralatan yang diperlukan antara lain wajan (penggorengan), sutil, serok, nampan, pisau, kompor gas LPG, tabung gas LPG, perajang bawang merah manual, perajang mekanis, hand sealer. Sedangkan bahan-bahan antara lain adalah tepung beras, tepung terigu, garam, minyak, kemasan, stiker/label dan bawang merah sebagai bahan baku yang dilakukan pembelian secara bertahap.

\section{c. Mempersiapkan Materi Pelatihan}

Untuk mempermudah pelaksanaan kegiatan, maka diberikan modul yang berisi tentang proses pembuataan bawang goreng, terdiri dari penyiapan bahan baku, bahan penunjang, pengemasan, pengepakan. Juga diberikan materi tentang manajemen usaha kecil diantaranya manajemen keuangan seperti cara pencatatan dan pembukuan keuangan sederhana, cara perhitungan harga pokok penjualan (HPP) dan perhitungan laba rugi. Demikian pula juga diajarkan manajemen pemasaran yakni cara dan strategi memasarkan hasil produksi.

d. Pelatihan Pengolahan Bawang Merah Kegiatan pelatihan telah dilaksanakan pada tanggal 24 Mei 2014 di rumah ibu Aniek Hernawati jalan Shinta No. 10-12 Desa Patihanrowo, sebagai kantor Majelis Ta'lim Khairul Ummah dan tempat kegiatan majelis berlangsung. Pelatihan dihadiri oleh 21 orang ibu-ibu dengan berbagai latar belakang pendidikan dan pekerjaan (Tabel 1).

Tabel 1.

Karakteritik Peserta Pelatihan IBM Agroindustri Bawang Merah Goreng

\begin{tabular}{|c|c|c|c|}
\hline Nomor & Uraian & Jumlah (orang) & $\%$ \\
\hline \multirow[t]{5}{*}{ 1. Umur } & $18-30$ & 5 & 23,81 \\
\hline & $31-40$ & 8 & 38,09 \\
\hline & $41-50$ & 3 & 14,29 \\
\hline & $51-60$ & 2 & 9,52 \\
\hline & $>60$ & 3 & 14,29 \\
\hline \multirow[t]{6}{*}{ 2. Pekerjaan } & - Ibu Rumah Tangga & 11 & 52,38 \\
\hline & -Wiraswasta & 3 & 14,29 \\
\hline & - Pedagang & 3 & 14,29 \\
\hline & • Guru TK/TU SD & 2 & 9,52 \\
\hline & - Pensiunan & 1 & 4,76 \\
\hline & - Pembantu Rumah tangga & 1 & 4,76 \\
\hline \multirow[t]{4}{*}{ 3. Pendapatan awal } & $0-300.000$ & 15 & 71,42 \\
\hline & $301.000-500.000$ & 2 & 9,52 \\
\hline & $501.000-700.000$ & 3 & 14,29 \\
\hline & $>700.000$ & 1 & 4,76 \\
\hline \multirow[t]{5}{*}{ 4. Pendidikan } & Tidak tamat SD & & \\
\hline & & & \\
\hline & SMP & & \\
\hline & Akademi & & \\
\hline & Sarjana & & \\
\hline
\end{tabular}


Pada tabel 1 dapat dilihat, umur peserta Ibm berkisar antara 18- 65 tahun, dengan persentase tertinggi pada interval usia 31-40 tahun yakni 38,09\%, selanjutnya usia 1830 tahun sebesar $23,81 \%, 14,29 \%$ antara usia 41-50 tahun dan lebih dari 60 tahun dan sisanya 9,52\% berusia antara 51-60 tahun. Dilihat dari pekerjaan, peserta kegiatan Ibm tardiri dari berbagai golongan yakni 52,384\% ibu rumah tangga, 14,29\% wirausaha (berjualan bahan pokok), 14,29\% pedagang (berjualan makanan keliling) dan sisanya 9,52\% bekerja di sekolah dan $4,71 \%$ pensiuan dan pembantu rumah tangga $4,76 \%$. Dilihat dari pendapatan, maka peserta Ibm memiliki pendapatan berkisar Rp 0,sampai Rp 900.000,-, dimana 71,42\% adalah mempunyai pendapatan < Rp 300.000,-, 14,29\% berpendapatan antara Rp 301.000-Rp 500.000,-; 9,52\% berpendapatan antara Rp 501.000,- - Rp 700.000,- dan hanya 4,76\% berpendapatan Rp $900.000,-$. Berdasarkan tingkat pendidikan formal, peserta Ibm berpendidilkan sangat beragam mulai dari tidak tamat SD.1 orang $(4,76 \%)$, SD 3 orang (14,29\%), SMP 5 orang (23.80\%), SMU 11 orang $(52,38 \%)$, Akademi 1 orang $(4,76 \%)$.

Perbedaan latar belakang pendidikan dan umur responden ini menyebabkan kemampuan menyerap materi pelatihan juga berbeda, sehingga ketrampilan yang diperoleh oleh setiap peserta berbeda-beda pula. Peserta dengan umur yang lebih tinggi (diatas 50 tahun) dan tidak tamat SD memiliki ketrampilan yang relatif lebih rendah dan lambat, sehingga mendapatkan tugas dan tanggung jawab yang relatif lebih ringan dan mudah dalam kegiatan Ibm tersebut. Misalnya

sebagai tenaga pengupas, perajang. Peserta dengan pendidikan SD dan SMP mendapatkan tugas untuk pengeringan, pengemasan produk ke box. Sedangkan peserta pendidikan SMA dan Akademi/Sarjana melakukan tugas penggorengan, administrasi keuangan dan produksi serta pemasaran.

Kegiatan pelatihan telah dilaksanakan pada tanggal 24 Mei 2014 di rumah ibu Aniek Hernawati jalan Shinta No. 10-12 Desa Patihanrowo, sebagai kantor Majelis Ta'lim Khairul Ummah dan tempat kegiatan majelis berlangsung. Pelatihan dihadiri oleh 21 orang ibu-ibu. Dalam pelatihan disampaikan materi tentang rencana melakukan kegiatan pemberdayaan ibu-ibu anggota majelis dan tujuan kegiatan pemberdayaan yakni terbentuknya kelompok ekonomi produktif dalam Majelis Ta'lim. Dengan kegiatan tersebut diharapkan akan mampu meningkatkan kemandirian ibu-ibu anggota Majelis Ta'lim secara ekonomi. Disamping itu juga disampaiakan tentang cara pengolahan bawang menjadi bawang goreng, manajemen usaha kecil khususnya manajemen keuangan sederhana dan manajemen pemasaran serta manajemen organisasi (Lampiran 4).

\section{e. Pembentukan Kelompok Pengolah Bawang Merah}

Dalam rangka terlaksananya kegiatan pemberdayaan masyarakat ini, maka dibentuklah kelompok pengolah bawang merah yang terdiri dari 2 kelompok yang masing-masing berjumlah 10 orang. Kelompok inti terdiri dari Ketua, Wakil Ketua, Kepala Bagian Keuangan, Kepala Bagian Produksi, Kepala Bagian Pemasaran, dimana masing-masing bagian dibantu oleh satu tenaga kerja. Kelompok ini yang bertanggung jawab secara penuh dan selalu aktif dalam kegiatan kelompok pengolah bawang merah dalam 
melakukan produksi rutin. Didalam perkembangannya ketika order permintaan bawang goreng meningkat, anggota majelis lain yang karena beberapa alasan pribadi tidak bisa full time bekerja untuk kelompok pengolah bawang merah ikut membantu.

\section{a.1. Manajemen Organisasi}

Tim manajemen pengolah bawang merah terdiri dari Ketua, Wakil Ketua, bagian produksi, pemasaran, keuangan yang masing-masing melakukan tugas sebagai berikut. Ketua : bertugas dan bertanggung jawab secara menyeluruh dalam menentukan dan mengambil keputusan terkait dengan kegiatan produksi, keuangan, pemasaran.

Wakil Ketua : bertugas membantu Ketua dalam mengelola organisasi pengolah bawang goreng khususnya melakukan monitoring dan pengendalian kegiatan.

Kepala Bagian Produksi: bertugas dan bertanggung jawab melakukan kegiatan produksi mulai dari penyiapan bahan baku dan penunjang, menentukan jadwal dan volume produksi, pengemasan dan pelabelan sampai produk bawang goreng siap dipasarkan. Dalam melaksanakan tugasnya Kepala Bagian Produksi dibantu oleh seorang karyawan.

Kepala Bagian Keuangan : bertugas dan bertanggung jawab terhadap kegiatan pengelolaan keuangan masuk dan keluar, mulai dari penyusunan rencana anggaran belanja dan penerimaan sederhana sampai kepada pelaporan keungan dalam kegiatan pengolahan bawang goreng. Pelaporan keuangan dilakukan setiap kali dilakukan kegiatan produksi atau ada order bawang goreng.

Kepala Bagian Pemasaran : bertugas dan betanggung jawab terhadap pengelolaan kegiatan pemasaran, mulai dari menentukan atau mencari pasar dan memantau pasar.

\section{a.2. Manajemen Produksi}

Kegiatan produksi dilakukan secara rutin yakni seminggu dua kali seminggu, yakni mengambil hari yang tidak ada kegiatan pengajian dengan kapasitas produksi 10 $\mathrm{kg}$ bahan baku per hari atau sekitar 24 botol produk bawang goreng

@ 100 gram atau $80 \mathrm{~kg}$ per bulan sama dengan

192 botol@100 gram. Tetapi apabila ada order permintaan secara khusus akan dilakukan produksi diluar jadwal dengan menyesuaikan jadwal pengajian Majelis Ta'lim.

Kegiatan produksi dilakukan dengan tahapan sebagai berikut:

- Persiapan produksi yakni menyediaan bahan baku dan penunjang serta peralatan yang dibutuhkan dalam proses produksi.

- Pelaksanaan produksi yang dimulai dengan pemilihan bahan baku yang baik, pengupasan, perajangan, pemberian bumbu, penggorengan, pengemasan dan pelabelan.

\section{a.3. Manajemen Pemasaran}

Untuk pemasaran hasil bawang goreng dapat dilakukan dengan beberapa metode yakni penjualan langsung dan penjualan tidak langsung, baik melalui sistem konsinyasi maupun advertising (periklanan).

\section{a.4. Manajemen Keuangan}


Dalam masalah keuangan, dilakukan beberapa kegiatan antara lain adalah:

- Sistem pembukuan keuangan sederhana yakni arus uang masuk dan keluar (cash flow), yakni mencatat semua pengeluaran dan penerimaan

- Melakukan perhitungan Laba rugi usaha Melakukan perhitungan Harga Pokok

- Penjualan

\section{f. Pendampingan Implementasi Hasil Pelatihan}

Setelah dilakukan pelatihan maka tahap selanjutnya adalah tahap implementasi hasil pelatihan dengan melakukan kegiatan pengolahan bawang merah menjadi bawang goreng secara mandiri oleh ibu-ibu anggota majelis. Dalam tahap ini pengabdi bertindak sebagai pendamping dan memberikan arahan dan bimbingan dalam melakukan proses pengolahan sampai menjadi produk jadi yang siap dipasarkan dan juga membantu melakukan penetrasi pasar produk. Pendamping juga melakukan bimbingan dan pendampingan dalam memasarkan hasil produksi bawang goreng ke berbagai tempat dan daerah sesuai dengan peluang pasar yang dapat dijangkau.

\section{g.Tehnologi Pembuatan Bawang Merah Goreng 1. Persiapan Bahan Dan Alat}

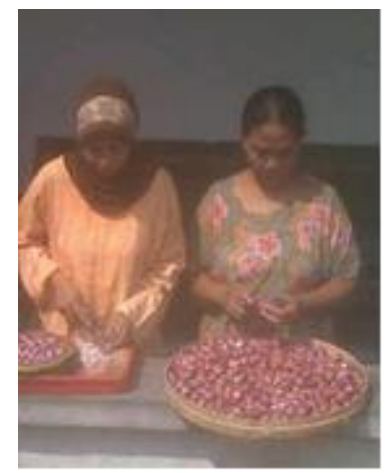

Bahan yang diperlukan untuk pembuatan bawang merah goreng adalah bawang merah kualitas super (berwarna merah cerah, diameter umbi 1,8-2 cm, belum muncul tunas, umbi padat berisi), tepung beras, tepung terigu, garam, minyak goring kemasan botol plastic, stiker/label dan gas LPG.

Sedangkan alat yang diperlukan adalah wajan (penggorengan), sutil, serok, nampan, pisau, toples plastic, kompor gas LPG, tabung gas LPG, perajang bawang merah manual, talenan, hand sealer (alat penyegel), spinner (peniris minyak)

\section{Proses Pengolahan Bawang Goreng a). Pengupasan atau pembuangan kulit}

Untuk menghasilkan bawang goreng yang baik maka gunakan bahan baku bawang merah yang masih segar dengan kulit bawang merah yang kering dan ukuran besar (diameter $2 \mathrm{~cm}$ ), belum muncul tunas, umbi padat berisi. Hal ini untuk memudahkan dalam proses pemotongannya, karena bawang goreng harus diiris tipis. Setelah tersedia bawang merah kualitas pilihan maka langkah pertama adalah mengupas atau membuang kulit luarnya. Pengupasan dapat dilakukan dengan menggunakan pisau dapur yang tajam atau saat ini sudah banyak perusahaan mesin 
industri yang menyediakan pengupas bawang merah. Dalam keiatan Ibm ini masih digunakan cara tradisional yaitu mengupas dengan pisau. Proses pengupasan ini memerlukan waktu sekitar 1 jam untuk mengupas 10 kilogram bawang merah segar dan tenaga kerja yang dibutuhkan 2 orang.

\section{b).Pengirisan}

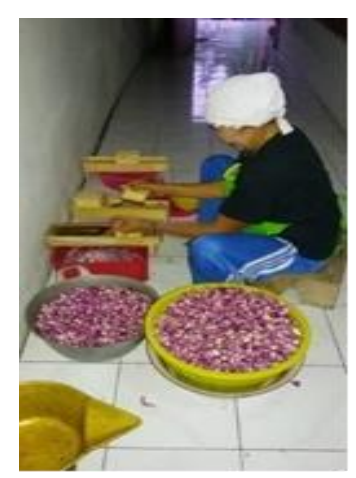

Bawang merah yang telah dikupas, selanjutnya dicuci dan dilakukan pengirisan. Irisan yang baik adalah yang tipis dan seragam, hal ini dapat diperoleh dengan cara embuang ujung bawang merah bawah dan atas yang tidak rata. Proses mengiris tipis bawang merah dapat dilakukan dengan dua cara yakni secara manual yaitu menggunakan perajang bawang merah, agar potongan yang dihasilkan merata dan secara mekanis yakni menggunakan mesin perajang bawang merah yang saat ini banyak ditawarkan oleh perusahaan mesin industri. Cara mekanis ini diperlukan apabila akan menggoreng dalam jumlah besar. Apabila irisan tidak seragam ketebalannya, hal ini akan berpengaruh terhadap kecepatan matang bawang goreng sehingga ada sebagian hasil gorengan yang gosong dan sebagian lagi kurang matang. Setelah pengirisan selesai kemudian bawang merah irisan ditempatkan pada wadah/baskom. Proses pengirisan secara manual memerlukan waktu 0,5 jam untuk 10 kilogram bawang merah dengan 2 orang tenaga kerja.

\section{c).Pemberian bumbu}

Bawang merah yang telah diiris tipis, ditambahkan garam 1 sendok teh atau sesuai selera lalu aduk rata dan diamkan sebentar. Setelah itu taburi tepung teriga dan tepung beras yang telah dicampur rata. Untuk $1 \mathrm{~kg}$ bawang merah, taburi tepung campuran terigu dan beras sebanyak 1 sendok makan, aduk rata lalu diamkan lagi sebentar. Tepung dan garam membuat bawang goreng menjadi renyah dan gurih. Proses pemberian bumbu berlangsung sekitar 5 menit. 


\section{d). Menggoreng}

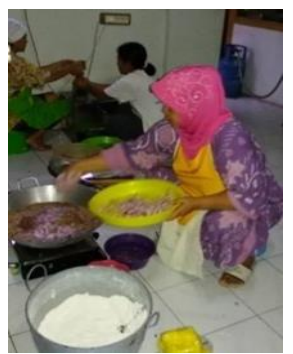

Tahap selanjutnya adalah meggoreng. Proses menggoreng dapat dilakukan dengan wajan dapur biasa atau penggorengan yang dirancang khusus. Penggorengan dalam jumlah besar akan lebih efisien apabila menggunakan penggorengan khusus/besar. Pada waktu proses pemasakan, gunakan banyak minyak dan dengan api yang kecil, agar hasil gorengan tidak cepat gosong. Selama menggoreng aduk semua bawang merah sampai matang merata hingga berwarna kekuningan, lalu angkat dan tiriskan hingga benar-benar kering. Satu hal yang harus diingat, angkatlah bawang goreng ketika sudah berwarna kuning. Jangan menunggu sampai hasil gorengan tersebut berwarna cokelat. Panasnya minyak ketika bawang goreng tersebut ditiriskan akan membuat warna bawang berubah menjadi cokelat kehitaman dan menghasilkan rasa yang pahit. Proses penggorengan secara manual dengan menggunakan 2 wajan, memerlukan waktu 2,5 jam untuk 10 kilogram bahan baku.

\section{e). Meniriskan}

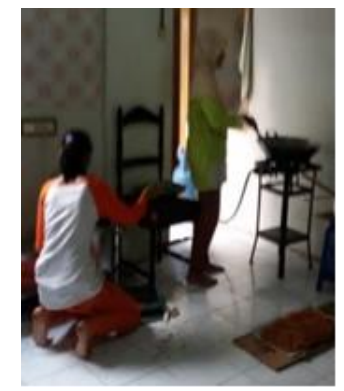

Setelah diangkat dari penggorengan, hasil gorengan bawang merah ditiriskan untuk membuang minyak yang masih menempel pada bawang goreng. Minyak ini harus dihilangkan karena apabila masih banyak kandungan minyak pada bawang goreng, akan menyebabkan bawang goreng tidak tahan lama disimpan atau cepat tengik. Proses penirisan dapat dilakukan seperti biasa dengan serok dapur atau penirisan dengan mesin peniris (spinner). Untuk penggorengan jumlah besar dan hasilyang sempurna, maka perlu dilakukan degan mesin spinner. Penggunaan spinner ini dianjurkan untuk pengorengan bawang merah dalam jumlah besar/skala indutri, karena hasil bawang goreng yang ditiriskan menggunakan spinner lebih kering, renyah, dan daya tahan simpan sampai 1-2 tahun. Sedangkan apabila menggoreng dalam jumlah sedikit cukup ditirskan dengan serok dan selanjutnya di tempatkan pada suatu wadah (nampan) yang dialasi kertas tisuue untuk menyerap minyaknya. Proses penirisan memerlukan waktu 25 menit untuk 10 kilogram bawang merah. 


\section{f). Pengemasan dan Pelabelan}

Setelah matang, masukkan bawang goreng pada wadah/kemasan yang kedap udara. Untuk kemasan bisa dikemas dalam plastik kempling, toples, botol plastik dll sesuai selera. Yang perlu diperhatikan disni adalah kemasan yang digunakan hendaknya yang kedap udara agar bawang goreng tidak melempem. Namun sebelum dimasukan kedalam toples, pastikan bawang goreng dalam keadaan dingin dan minyaknya sudah habis. Hal ini dilakukan agar menghasilkan bawang goreng yang renyah dan kering serta tahan lama. Waktu yang diperlukan untuk pengemasan dan labeling adalah 30 menit untuk 10 kilogram bahan baku. Saat ini kapasitas produksi adalah sebesar 10 kilogram per hari dengan jumlah tenaga kerja sebanyak 10 orang dan waktu produksi selama 5 jam. Interval produksi dilakukan 2 kali per minggu atau 8 kali per bulan dengan hasil produksi sebanyak 192 botol @ 100 gram atau 19,2 kilogram bawang goreng.

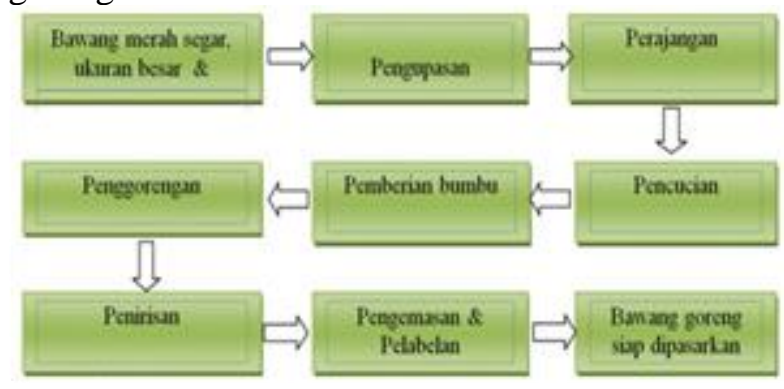

Gambar 1. Proses Pengolahan Bawang Merah Goreng

\section{h. Karakteristik Produk}

Produk bawang goreng dikemas dalam botol dengan berat @ 100 gram, berlabel dengan Merk "BagorKU", dengan nomor P-IRT : 211351801012019 . Sebetulnya pada awal produksi pernah dilakukan pengemasan plastik dengan berat bersih 100 gram bermerk dan berlabel tetapi dalam perkembangan proses pemasaran konsumen lebih menyukai kemasan botol dikarenakan lebih praktis, tidak perlu memindahkan ke wadah lain untuk menjaga agar tidak melempem. Selanjutnya produk dikemas dalam dus @ isi 69 botol. Saat ini karena sudah banyak konsumen yang mengulangi pembelian (repeat), maka sedang dirancang kemasan ulang bawang goreng (refill) @ seberat 85 gram (Tabel 2).

Tabel 2.

\begin{tabular}{|c|c|c|}
\hline Karakteristi & Bawang Me & ah Goreng " \\
\hline & & BAWANG \\
\hline $\mathrm{NO}$ & KARATERISTIK & MERAH GORENG \\
\hline & & KHAS NGANJUK \\
\hline 1 & Ukuran & Sedang \\
\hline 2 & Warna & Kuning cerah \\
\hline 3 & Aroma & $\begin{array}{l}\text { Harum aroma } \\
\text { bawang merah }\end{array}$ \\
\hline 4 & Kolesterol & Rendah \\
\hline 5 & Daya simpan & 1 tahun \\
\hline 6 & Kemasan & $\begin{array}{c}\text { Botol plastik isi } \\
100 \text { gram net }\end{array}$ \\
\hline 7 & Label & $\begin{array}{c}\text { Bawang Merah } \\
\text { Goreng "BagorKu" }\end{array}$ \\
\hline 8 & Harga jual & Rp. 22.500 \\
\hline 9 & Ijin Produksi & $\begin{array}{c}\text { P-IRT: } \\
211351801012019\end{array}$ \\
\hline 10 & Kode halal & $\begin{array}{c}\text { Sedang dalam } \\
\text { proses ajuan }\end{array}$ \\
\hline
\end{tabular}




\section{j. Pemasaran}

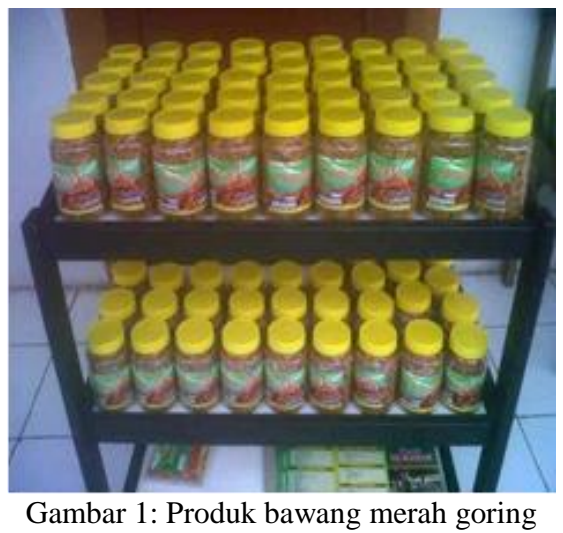

Pembentukan jaringan pasar bawang merah goreng dilakukan dengan beberapa metode yakni :

a) Personal Selling yaitu cara pemasaran secara langung kepada konsumen. Dalam model pemasaran ini dilakukan dengan memanfaatkan kenalan, teman dan saudara di beberapa daerah, baik sebagai konsumen akhir maupun bertindak sebagai agen. Dengan cara ini produk bawang goreng sudah dipasarkan ke berbagai daerah seperti Kertosono, Nganjuk, Malang, Surabaya, Pacitan, Tasikmalaya, Jakarta, Tangerang, Depok, Pangkal Pinang, Kuala Lumpur (Malaysia) dan sedang diupayakan ke Nederland (Belanda).

b). Sistem konsinyasi ke beberapa koperasi, antara lain Mini Market "Mikro" Kertosono, Koperasi Pegawai Negeri (KPN) Universitas Brawijaya Malang, Toko 76 Malang, Toko Bilka Surabaya, Koperasi Pegawai Sandi Negara (Kopegsaneg) Jakarta, Koperasi Pegawai Negeri Pengadilan Negeri Pangkal Pinang.

c). Advertising (periklanan) dengan menggunakan internet melalui pembuatan web yang bisa diakses pada www.bagorku.com.

d). Kontrak penjualan partai yaitu order pesanan khusus untuk bingkisan lebaran. Pada musim lebaran tahun 2014 ini mendapat order sebanyak 1850 botol dari Koperasi Pegawai Lembaga Sandi Negara Jakarta senilai Rp. 29.504.000,--

Dari beberapa cara tersebut, persentase terbesar adalah pada penjualan partai. Saat ini sudah terbentuk beberapa distributor di beberapa kota antara lain seperti Jakarta, Malang, Pangkal Pinang, Tasikmalaya.

\section{j. Analisis Kelayakan Pengolahan Bawang Merah Goreng}

Sektor pertanian dalam wawasan agribisnis dengan perannya dalam perekonomian nasional memberikan beberapa hal yang menunjukan keunggulan yang patut dipertimbangkan dalam pembangunan nasional. Keunggulan tersebut antara lain melihat tingginya nilai tambah agroindustri. Sifat bawang merah yang mudah rusak dan seasonable berakibat harga berfluktuasi tajam. Kondisi ini mendorong untuk melakukan pengembangan pengolahan yang memberikan peluang mendatangkan keuntungan. 
Dari keadaan tersebut di atas maka dalam kegiatan pemberdayaan masyarakat Majelis Ta'lim ini perlu dilengkapi dengan analisis kelayakan usaha yaitu struktur biaya, pendapatan, tingkat efisiensi, nilai Break Event Point dan Break Event Point, dan nilai tambah dari usaha

pengolahan bawang goreng. Analisa kelayakan usaha yang terdiri dari:

1) Analisa keuntungan/pendapatan usaha,

2) Analisa efisiensi usaha (R/C Ratio),

3) Analisa BEPq dan analisa BEPr,

4) Analisis Harga Pokok Penjualan

5) Analisa nilai tambah.

Tabel 3.

Analisis Keuntungan Pengolahan Bawang Goreng

Dalam Satu Kali Proses Produksi

\begin{tabular}{|c|c|c|c|c|c|}
\hline NO & URAIAN & JUMLAH & HARGA/UNIT & TOTAL (RP) & $\%$ \\
\hline I & BIAYA TETAP & & & & \\
\hline & Sewa lahan & & & 2.740 & 0,1 \\
\hline & Penyusutan alat & & & 3.611 & $\overline{0,1}$ \\
\hline & Jumlah Biaya Tetap & & & 6.351 & $\overline{0,2}$ \\
\hline II & BIAYA VARIABEL & & & & \\
\hline 1 & Bahan baku (kg) & 90 & 17.000 & 1.530 .000 & 53,7 \\
\hline 2 & Minyak goreng (liter) & 27 & 12.800 & 345.600 & 12,1 \\
\hline 3 & Tepung terigu $(\mathrm{kg})$ & 4.5 & 7.200 & 32.400 & $\overline{1,1}$ \\
\hline 4 & Tepung beras $(\mathrm{kg})$ & 4.5 & 9.000 & 40.500 & $\overline{1,4}$ \\
\hline 5 & LPG (Tabung $3 \mathrm{~kg}$ ) & 4.5 & 15.000 & 67.500 & $\overline{2,4}$ \\
\hline 6 & Garam (bungkus) & 2 & 500 & 1.000 & 0,04 \\
\hline 7 & Tenaga kerja $(\mathrm{HOK})$ & 10 & 43.500 & 435.000 & 15,3 \\
\hline 8 & Kemasan dan label (botol) & 212 & 1.750 & 371.000 & 13,0 \\
\hline 9 & Transportasi & 20.000 & & 20.000 & 0,7 \\
\hline & Jumlah Biaya Variabel & & & 2.843 .000 & 99,8 \\
\hline & Total Biaya Produksi & & & 2.849 .351 & 100 \\
\hline III & Produksi $(\mathrm{kg})$ & 21,2 & & & \\
\hline & Harga jual (Rp/kg) & & 187.750 & & \\
\hline IV & Penerimaan $(\mathrm{Rp})$ & & & 3.980 .300 & \\
\hline $\mathrm{V}$ & Keuntungan (Rp) & & & 1.130 .949 & 40 \\
\hline VI & $\mathrm{R} / \mathrm{C}$ ratio & & & 1,40 & \\
\hline VII & BEP Harga $(\mathrm{Rp} / \mathrm{kg})$ & & & 134.403 & \\
\hline $\begin{array}{l}\text { VIII } \\
\end{array}$ & BEP Produksi $(\mathrm{Kg})$ & & & 15,18 & \\
\hline
\end{tabular}

\section{1). Analisa Pendapatan/Keuntungan Usaha}

Usaha bawang goreng UD. BagorKu memiliki kapasitas produksi bawang merah $90 \mathrm{Kg} /$ proses produksi, dengan harga bahan baku Rp 19.000,-/kg. Dengan jumlah bahan baku tersebut setelah dilakukan penggorengan akan dihasilkan bawang goreng sebesar 0,24 x $90 \mathrm{~kg}=21,2 \mathrm{~kg}$ dengan menggunakan pengeringan spinner. Untuk mengolah sejumlah bahn baku tersebut diperlukan biaya produksi total sebesar Rp. 2.849.351,- dan penerimaan sebesar Rp 3.980.300 sehingga diperoleh keuntungan sebesar Rp 1.130.949,-- 


\section{2). Analisis Efisiensi Usaha.}

Untuk mengetahui efisiensi usaha pengolahan bawang merah goreng dilakukan dengan analisis $\mathrm{R} / \mathrm{C}$ ratio, yakni rasio (perbandingan antara penerimaan total dengan biaya produksi total). Berdasarkan perhitungan $\mathrm{R} / \mathrm{C}$ ratio diperoleh besaran $\mathrm{R} / \mathrm{C}$ ratio sebesar 1,4, artinya setiap $\mathrm{Rp}$ 1,- biaya yang dikeluarkan akan memberikan penerimaan sebesar Rp 1,4 yang berarti menguntungkan dengan tingkat keuntungan sebesar $40 \%$.

\section{3). Analisis Break Even Point (BEP)}

Analisis Break Even Point (BEP) adalah suatu analisis untuk mengetahui batas penentuan produksi untung atau rugi. Ada dua macam analisis BEP yakni BEP Volume produksi (BEPq) dan BEP Harga (BEPPr). Berdasarkan hasil perhitungan diperoleh hasil BEPPr dicapai pada saat harga Rp 134.403/kilogram; hal ini berarti bahwa keuntungan akan diperoleh apabila harga jual produk diatas atau lebih besar dari Rp 134.403,-/kilogram. Sedangkan PEPq terjadi pada saat produksi mencapai 15.18 kilogram, ini berarti bahwa keuntungan akan diperoleh bila produksi lebih besar dari 15,18 kilogram (Tabel 3). Ini berarti bahwa agar pengolahan bawang merah goreng menguntungkan maka pengolah harus melakukan produksi diatas 15,18 dalam sekali proses produksi dan harga jual diatas Rp 134.403,-. Berdasarkan hal ini maka kegiatan pengolahan bawang merah goreng yang dilakukan oleh Majelis Ta'lim sudah menguntungkan.

\section{4). Perhitungan Harga Pokok Penjualan}

Harga pokok penjualan adalah jumlah seluruh biaya produksi yang dikeluarkan untuk memproduksi barang. Harga pokok penjualan ini bermanfaat untuk menentukan harga jual produk dengan menambahkan sejumlah tertentu keuntungan usaha yang diinginkan (disebut marjin). Berdasarkan hasil perhitungan yang dilakukan maka harga pokok penjualan bawang merah goreng adalah sebagai berikut (Tabel 4).

Tabel 4.

Perhitungan Harga Pokok Penjualan Bawang Goreng

\begin{tabular}{llrrr}
\hline No & \multicolumn{1}{c}{ Uraian } & Jumlah (unit) & Harga/unit & \multicolumn{1}{c}{ Total (Rp) } \\
\hline 1 & Bahan baku (kg) & 90 & 17.000 & 1.530 .000 \\
\hline 2 & Minyak goreng (liter) & 27 & 12.800 & 345.600 \\
\hline 3 & Tepung terigu (kg) & 4.5 & 7.200 & 32.400 \\
\hline 4 & Tepung beras (kg) & 4.5 & 9.000 & 40.500 \\
\hline 5 & LPG (taung 3 kg) & 4.5 & 15.000 & 67.500 \\
\hline 6 & Garam (bungkus) & 2 & 500 & 1.000 \\
\hline 7 & Tenaga kerja (HOK) & 10 & 43500 & 435.000 \\
\hline 8 & Kemasan dan label (botol) & 212 & 1.750 & 371.000 \\
\hline 9 & Transportasi & 20.000 & & 20.000 \\
\hline 10 & JUMLAH & 212 & & 2.843 .000 \\
\hline 11 & Produksi (botol) & & & 13.410 \\
\hline 12 & HPP & & & 5.364 \\
\hline 13 & Marjin 40\% & & $\mathbf{1 8 . 7 7 5}$ \\
\hline 14 & Harga jual distributor (Rp/botol) & & $\mathbf{2 2 . 5 0 0}$ \\
\hline 15 & Harga jual eceran (Rp/botol)
\end{tabular}


Dari Tabel 4 dapat dilihat bahwa harga pokok penjualan (HPP) bawang merah goreng adalah sebesar Rp 13.410,-/botol, sedangkan harga jual untuk distributor untuk mendapatkan keuntungan (marjin) sebesar 40\% adalah sebesar Rp 18.775,-/botol. Sedangkan harga eceran sebesar Rp 22.500,-/botol.

\section{5).Perhitungan Nilai Tambah Pengolahan Bawang Merah Goreng}

Salah tujuan melakukan proses pengolahan adalah untuk memperoleh nilai tambah pengolahan. Nilai tambah pengolahan adalah nilai yang diperoleh sebagai akibat melakukan kegiatan pengolahan terhadap bahan segar menjadi bahan olahan. Nilai tamba terdiri dari keuntungan pengolah sebagai imbalan atas modal dan manajemen yang telah dialokasikan dalam proses pengolahan dan imbalan tenaga kerja yang telah bekerja dalam proses pengolahan tersebut. Dari hasil analisis nilai tambah yang dilakukan maka pengolahan bawang merah menjadi bawang merah goreng menghasilkan nilai tambah pengolahan sebesar Rp 11.971,-/kilogram bahan baku dan rasio nilai tambah pengolahan sebesar $26,6 \%$. Artinya setiap pengolahan 1 kilogram bawang merah dengan nilai $\mathrm{Rp} 19.000,-/ \mathrm{kg}$ akan mendapatkan nilai tambah sebesar Rp 11.971/kg atau sebesar 26,6\%. Besaran nilai tambah tersebut dialokasikan kepada pengolah sebagai imbalan modal dan manajemen sebesar Rp 7.138/kilogram dengan rasio sebesar 59,6\% dan untuk imbalan tenaga kerja sebesar Rp 4,833,/kilogram dengan rasio sebesar 40,4\% (Tabel 5). Sedangkan proses pengolahan bawang merah menjadi bawang goreng memberikan marjin sebesar Rp 28.060,-/kg.

\section{Tabel 5.}

Perhitungan Nilai Tambah Pengolahan

Bawang Merah Menjadi Bawang Goreng

\begin{tabular}{clc}
\hline NO & \multicolumn{1}{c}{ URAIAN } & JUMLAH \\
\hline 1 & Hasil Produksi $(\mathrm{kg})$ & 21,2 \\
\hline 2 & Input Bahan Baku $(\mathrm{kg})$ & 90 \\
\hline 3 & Input Tenaga Kerja(HOK) & 10 \\
\hline 4 & Faktor Konversi & 0,24 \\
\hline 5 & Koefisien Tenaga Kerja & 0,11 \\
\hline 6 & Harga Produk (Rp/Kg) & 187.750 \\
\hline 7 & $\begin{array}{l}\text { Upah Tenaga Kerja } \\
\text { (Rp/HOK) }\end{array}$ & 43.500 \\
\hline \multirow{2}{*}{8} & $\begin{array}{l}\text { Harga Input Bahan Baku } \\
\text { (Rp/Kg) }\end{array}$ & 17.000 \\
\hline 9 & $\begin{array}{l}\text { Sumbangan Input Lain } \\
\text { (Rp/kg bahan baku) }\end{array}$ & 16.089 \\
\hline 10 & Nilai Produk (Rp/Kg) & 45.060 \\
\hline 11 & Nilai Tambah (Rp/Kg) & 11.971 \\
\hline 12 & Rasio Nilai Tambah $(\%)$ & 26,6 \\
\hline 13 & $\begin{array}{l}\text { Pendapatan Tenaga } \\
\text { Kerja(Rp/Kg) }\end{array}$ & 4.833 \\
\hline 14 & Bagian Tenaga Kerja(\%) & 40,4 \\
\hline 15 & Keuntungan (Rp/Kg) & 7.138 \\
\hline 16 & Tingkat Keuntungan & 59,6 \\
\hline 17 & $\begin{array}{l}\text { Marjin (Nilai Produk- } \\
\text { Bahan Baku) }\end{array}$ & 28.060 \\
\hline
\end{tabular}




\section{Evaluasi}

a. Untuk mengetahui respon masyarakat terhadap program IbM telah dilakukan pengukuran respon ibu-ibu anggota majelis terhadap keberadaan program melalui wawancara dengan menggunakan kuesioner. Dari hasil wawancara diketahui bahwa ibu-ibi anggota majelis ta'lim sangat senang akan keberadaan program IbM dan berharap kegiatan ini dapat berlanjut sehingga akan sangat membantu menambah pendapatan bagi keluarganya.

b. Untuk mengetahui keberhasilan pembentukan kelompok pengolah bawang merah menjadi bawang goreng, telah dilakukan pengamatan terhadap kinerja kelompok dalam tahap implementasi hasil. Dari pengamatan diketahui bahwa kelompok pengolah telah berjalan sebagaimana diharapkan, namun kelompok pemasaran belum berjalan dengan maksimal.

c. Untuk mengetahui kelayakan produk hasil olahan telah dilakukan uji indrawi dan uji pasar. Secara indrawi produk bawang goreng yang dihasilkan telah layak secara fisik yakni bawang goreng mempunyai penampilan warna kuning cerah, rajangan bagus dengan ketebalan yang seragam, rasa renyah dan gurih. Produk dikemas dalam botol plastik dengan ukuran @ 100 gram/botol, berlabel dan ber merk "BagorKu", kode produksi, tanggal kadaluarsa. Selanjutnya produk dikemas dalam karton berlabel dengan isi 69 botol/karton.

d. Pengukuran Kenaikan Pendapatan

Pengukuran kenaikan pendapatan ibu-ibu anggota majelis setelah mengikuti program IbM telah dilakukan, baik berdasarkan jumlah pendapatan yang diterimakan ketika kegiatan berlangsung atau melalui wawancara dengan kuesioner yang dilakukan. Secara menyeluruh peserta mengakatan bahwa dengan adanya kegiatan IbM ini mereka merasakan adanya kenaikan pendapatan seharihari yang sangat membantu keluarga dalam memenuhi kebutuhan keluarga yakni mengalami kenaikan pendapatan rata-rata sebesar $88,2 \%$ dari sebelum mengikuti program.

Tabel 6.

Perbedaan Rata-rata Pendapatan Peserta Ibm Sebelum dan Setelah Mengikuti kegiatan Ibm

\begin{tabular}{|c|c|c|c|}
\hline $\begin{array}{c}\text { Pendapatan } \\
\text { Sebelum }\end{array}$ & $\begin{array}{c}\text { Pendapatan } \\
\text { Sesudah } \\
\text { Ibm }\end{array}$ & $\begin{array}{c}\text { Kenaikan } \\
\text { Ibm }\end{array}$ & $\begin{array}{c}\text { Persentase } \\
(\mathrm{Rp})\end{array}$ \\
\hline 269.000 & 659.523 & 390.476 & 88,2 \\
\hline
\end{tabular}

\section{KESIMPULAN}

Dari hasil pelaksanaan Ibm dengan kegiatan Pemberdayaan Kelompok Majelis Ta'lim Melalui Pengembangan Agroindustri Bawang Goreng dapat disimpulkan bahwa:

1. Respon masyarakat sangat baik dan mendukung kegiatan IbM.

2. Perbedaan latar belakang pendidikan dan umur individu peserta Ibm, menyebabkan perkembangan kemandirian peserta dalam keikutsertaan dalam program Ibm tidak seragam.

3. Telah terbentuk kelompok pengolah bawang merah goreng dengan nama UD. Khairul Ummah 
4. Telah menghasilkan produk bawang merah goreng dengan merk "BagorKu" yang telah mendapatkan ijin dari Depkes dengan no P-IRT : P-IRT : 211351801012019

5. Telah terbentuk jaringan pasar baik secara langsung maupun model konsinyasi dengan beberapa Koperasi/ Toko di beberapa kota.

6. Pendapatan peserta Ibm meningkat rata-rata sebesar $88,2 \%$.

7. Usaha pengolahan bawang merah goreng dapat memberikan keuntungan sebesar $40 \%$, dengan

harga pokok penjualan sebesar Rp 22.500/botol @ 100 gram, BEP tercapai saat harga sebesar Rp 134.403,-/ kg atau 15,18 kilogram.

8. Proses pengolahan bawang merah goreng memberikan nilai tambah sebesar $26,6 \%$ yang dapat memberikan imbalan kepada tenaga kerja sebesar $40,4 \%$, berarti dapat membantu membuka lapangan kerja bagi masyarakat sekitarnya.

\section{DAFTAR PUSTAKA}

BPS Kabupaten Nganjuk, 2010. Kabupaten Ngajuk.

Direktorat Jenderal Pengolahan Dan Pemasaran Hasil Pertanian, 2006. Road Map

Pasca Panen, Pengolahan Dan Pemasaran Hasil Bawang. Jakarta

Kementan, 2012. Nilai Tambah Dari Olahan Bawang Merah.

http://widyatan.com/index.php/arsip/artik el/pengolahan-hasil-pertanian/229-irsapgoningsih-mp. diakses tanggal 27 Maret 2014

Taufik Yasin, 2013. Diskusi Bawang Merah. http://agritusi.com/archives/458 diakses 20 Maret 2013.

Wikipedia, 2013. Kabupaten Nganjuk. http://id.wikipedia.org/wiki/Kabupaten_N ganjuk diakses tanggal 15 Mei 2013. 